\title{
MicroRNAs in treatment-induced neuroendocrine differentiation in prostate cancer
}

\author{
Theresa Akoto', Divya Bhagirath², Sharanjot Saini² \\ 'Department of Cellular Biology and Anatomy, Augusta University, Augusta, GA 30912, USA. \\ 2Department of Biochemistry and Molecular Biology, Augusta University, Augusta, GA 30912, USA.
}

Correspondence to: Dr. Sharanjot Saini, Department of Biochemistry and Molecular Biology, Augusta University, 1410 Laney Walker Boulevard, Augusta, GA 30912, USA. E-mail: ssaini@augusta.edu

How to cite this article: Akoto T, Bhagirath D, Saini S. MicroRNAs in treatment-induced neuroendocrine differentiation in prostate cancer. Cancer Drug Resist2020;3:804-18. http://dx.doi.org/10.20517/cdr.2020.30.

Received: 29 Apr 2020 First Decision: 30 Jun 2020 Revised: 28 Jul 2020 Accepted: 31 Jul 2020 Available online: 12 Oct 2020

Academic Editor: Vincent C. O. Njar Copy Editor: Cai-Hong Wang Production Editor: Jing Yu

\begin{abstract}
Prostate cancer is a condition commonly associated with men worldwide. Androgen deprivation therapy remains one of the targeted therapies. However, after some years, there is biochemical recurrence and metastatic progression into castration-resistant prostate cancer (CRPC). CRPC cases are treated with second-line androgen deprivation therapy, after which, these CRPCs transdifferentiate to form neuroendocrine prostate cancer (NEPC), a highly aggressive variant of CRPC. NEPC arises via a reversible transdifferentiation process, known as neuroendocrine differentiation (NED), which is associated with altered expression of lineage markers such as decreased expression of androgen receptor and increased expression of neuroendocrine lineage markers including enolase 2, chromogranin A and synaptophysin. The etiological factors and molecular basis for NED are poorly understood, contributing to a lack of adequate molecular biomarkers for its diagnosis and therapy. Therefore, there is a need to fully understand the underlying molecular basis for this cancer. Recent studies have shown that microRNAs (miRNAs) play a key epigenetic role in driving therapy-induced NED in prostate cancer. In this review, we briefly describe the role of miRNAs in prostate cancer and CRPCs, discuss some key players in NEPCs and elaborate on miRNA dysregulation as a key epigenetic process that accompanies therapy-induced NED in metastatic CRPC. This understanding will contribute to better clinical management of the disease.
\end{abstract}

Keywords: MicroRNAs, neuroendocrine differentiation, castration-resistant prostate cancer, epigenetics, oncomirs, tumor suppressors, androgen deprivation therapy 


\section{INTRODUCTION}

Prostate cancer $(\mathrm{PCa})$ remains the second leading cause of cancer death in men after lung cancer, according to the American Cancer Society ${ }^{[1]}$. In 2020, there will be about 191,930 estimated new cases of PCa in men, of which 33,330 are expected to die from the disease ${ }^{[2]}$. The prostate-specific antigen (PSA) test is aimed at detecting PCa at an early stage to monitor disease progression ${ }^{[3]}$. Patients with PCa can be treated by way of active surveillance, radiation and surgery depending on the stage of the tumor ${ }^{[4,5]}$. Androgens stimulate PCa cells to grow since tumor cells express androgen receptor $(\mathrm{AR})^{[6]}$. As a result, androgen deprivation therapy (ADT) is mostly used for treating PCa. After treatment, the disease declines in most patients for some time, but then progresses to castration-resistant prostate cancer (CRPC), which does not respond to hormonal therapy ${ }^{[7]}$. Since AR signaling still drives CRPC, drugs have been designed to either inhibit intratumoral androgen synthesis [e.g., abiraterone (ABI)] or more effectively inhibit AR signaling [e.g., enzalutamide (ENZ) $]^{[8,9]}$. However, this treatment of CRPC ultimately leads to the transdifferentiation of CRPC to neuroendocrine prostate cancer (NEPC), an aggressive subtype of CRPC ${ }^{[10-12]}$. NEPC arises via a reversible transdifferentiation process, known as neuroendocrine differentiation (NED), which is associated with altered expression of lineage markers such as decreased expression of AR and increased expression of neuroendocrine (NE) lineage markers including enolase 2 (ENO2), chromogranin A (CHGA) and synaptophysin (SYP) ${ }^{[13,14]}$. NEPC displays NE cell phenotype and is an AR-negative variant. Since it is AR-negative, these patients show low serum PSA and resistance to AR-targeted therapy ${ }^{[15,16]}$. As a result, there is a need to identify and develop novel therapies for targeting AR-independent mechanisms in advanced PCa. Developing novel therapies require better understanding of the disease. It has been hypothesized that cellular heterogeneity may contribute to the eventual failure of AR-targeted agents ${ }^{[17]}$. MicroRNAs (miRNAs) are small non-coding RNAs that are important gene regulators, acting primarily by suppressing gene expression post-transcriptionally via sequence-specific interactions with the 3 '- untranslated regions of cognate mRNA targets ${ }^{[18,19]}$. miRNA dysregulation has been implicated in many cancers ${ }^{[20]}$. This review seeks to address the association of miRNAs with NEPC.

\section{PROSTATE GLAND CELL TYPES AND EMERGENCE OF THERAPY-INDUCED NEPC}

The prostate gland is composed of three main cell types (luminal cells, basal cells and NE cells) [Figure 1]. Luminal cells are the most dominant cell type, expressing keratins (K8, K18), AR and PSA ${ }^{[21]}$. Basal cells are the second most dominant cell type and do not express AR and PSA. These cells also express keratins (K14, K5) and stem cell marker p63. NE cells are rare cells interspersed between the basal cells, which express ENO2, CHGA and SYP ${ }^{[6,22]}$. The majority of patients diagnosed with CRPC are characterized by high levels of serum PSA ${ }^{[23]}$. Histologically, prostate tumors are luminal in nature though tumors have also been reported to arise from basal cells, which progress to PCa with luminal-like features ${ }^{[6,24,25]}$. However, after treatment with AR pathway inhibitors such as ENZ and ABI, these luminal cells transdifferentiate to form neuroendocrine cells leading to therapy-induced PCa (NEPC), an aggressive subtype of CRPC characterized by low PSA and no AR signaling ${ }^{[26-30]}$. A small percentage of PCa patients present de novo NEPCs that arise directly from NE cells of the prostate gland, and these tumors are independent of treatment as shown in Figure $1^{[31]}$. Therapy-induced NEPC represents a spectrum of phenotypes, including focal NED in prostate adenocarcinomas, mixed NE/adenocarcinoma or pure NE tumors (small cell/large cell ${ }^{[26]}$.

\section{NEPC: molecular features and epigenetics}

$\mathrm{NEPC}$ is a highly aggressive subtype of $\mathrm{PCa}^{[10]}$. It has been shown to progress aggressively, metastasizing primarily to the visceral organs, tissues and sometimes to the bone ${ }^{[32]}$. Histologically, it is characterized by poor differentiation in tumors, coil-like, or organoid shaped cells which appear basophilic with distinct nucleoli ${ }^{[32]}$. In addition, studies have shown that, patients confirmed with NEPC usually develop visceral metastases, have low PSA levels and have frequent loss of retinoblastoma $1\left(R b_{1}\right)$ and tumor suppressor p53 (TP53) genes ${ }^{[10,33,34]}$. 


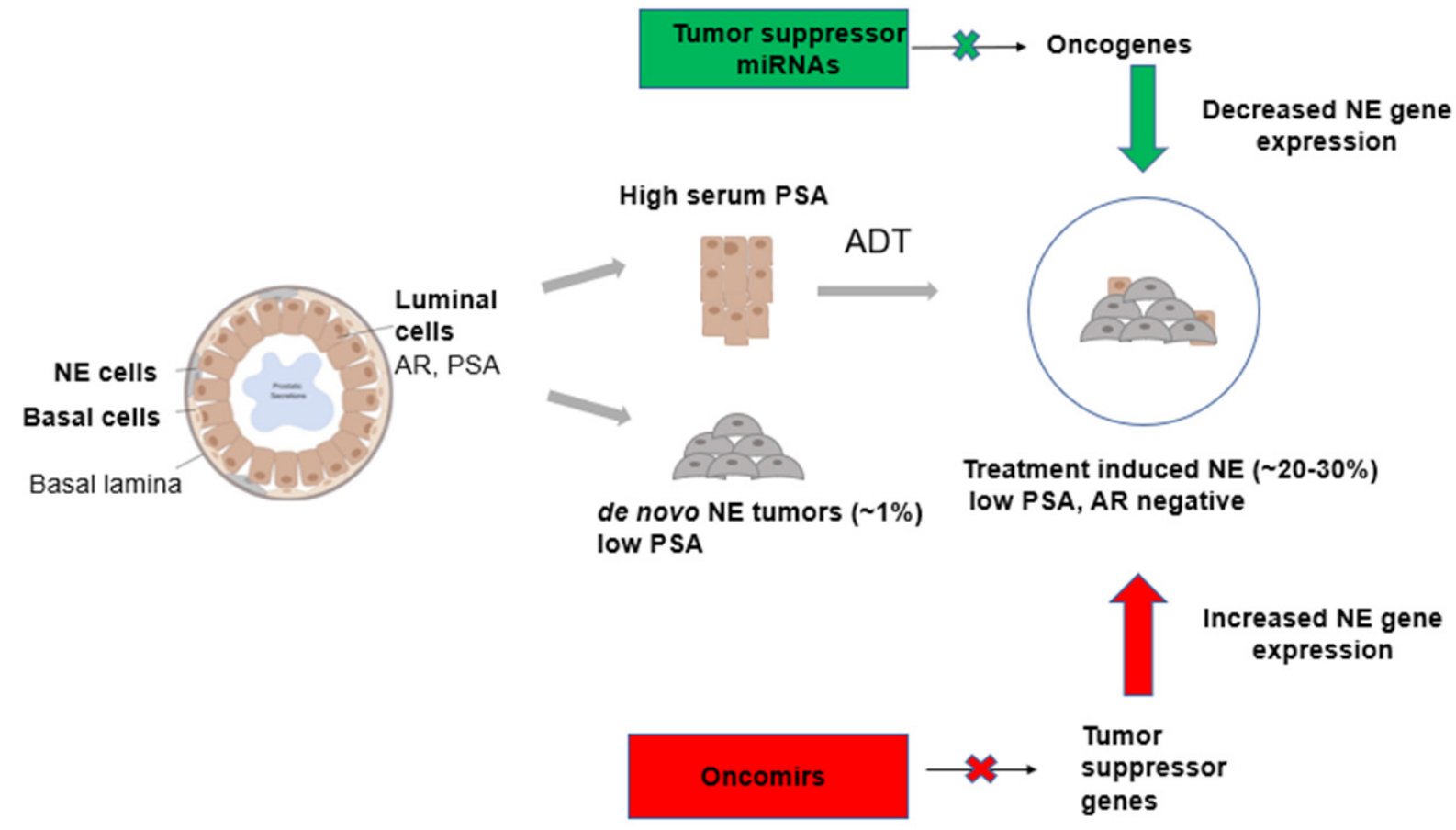

Figure 1. Prostate cancer cell of origin and miRNA regulation. Schematic illustration showing the different cell types of the prostate gland contributing to the formation of CRPC and SCNC and the roles of miRNAs in the regulation of therapy-induced NE. miRNA: MicroRNA; CRPC: castration-resistant prostate cancer; SCNC: small cell neuroendocrine carcinoma; NE: neuroendocrine

Epigenetic changes are associated with many human cancers particularly with PCa development and progression ${ }^{[35,36]}$. Epigenetics is usually defined as heritable changes in regulating gene expression without changes in the DNA sequence. Histone modifications, DNA methylation, and miRNAs have been shown as epigenetic modifications that play crucial roles in PCa growth and metastasis ${ }^{[37-40]}$. These epigenetic changes have a well-established role in regulating cellular plasticity in $\mathrm{NEPC}^{[41]}$. DNA methylation is a key epigenetic modification that affects transcription and development ${ }^{[42]}$. Chromatin flux in NEPC is shown to be regulated by $\mathrm{Rb} 1$ and $\mathrm{TP} 53$, which can prevent $\mathrm{NED}^{[43]}$. Inactivation of both $\mathrm{TP} 53$ and $R b_{1}$ is required to reprogram transcriptional profiles and chromatin accessibility landscapes of normal prostate epithelial cells to human NEPC/small cell prostate cancer. Interestingly, when retinoblastoma protein (pRb) is lost, cells exhibit overexpression of DNA methyltransferase 1 (DNMT1) which leads to an accumulation of DNMT1 protein $^{[44]}$. Studies have shown that DNMT1 is overexpressed in NEPC ${ }^{[45]}$. Furthermore, DNA methylation has been observed to cause downregulation of miR-145, miR-127, miR-124a, and miR-34, suggesting that miRNA epigenetic mechanisms could regulate the tumor epigenome ${ }^{[46]}$. Apart from the loss of TP53 and $R b_{1}$, the activation of mitotic programs involving an upregulation of Aurora kinase A (AURKA) and amplification of MYCN have been shown to cause NED due to androgen depletion ${ }^{[47]}$. AURKA and MYCN functionally work together and can induce a NE phenotype in prostate cells, and the overexpression and amplification of MYCN in NEPC tumors and in about $5 \%$ of PCas is associated with NED as well as stabilization of AURKA ${ }^{[10]}$. Histone methylation and acetylation are the most common types of histone modifications seen in chromatin which are regulated by enzymes such as: histone acetyltransferases, histone deacetylases, histone methyltransferases (HMTs) and histone demethylases ${ }^{[48]}$. Enhancer of zeste homolog $2(\mathrm{EZH} 2)$ is a HMT that is also overexpressed in NEPC and leads to cellular plasticity during transdifferentiation, and the expression of EZH2 is also regulated directly by miR-101 ${ }^{[49,50]}$. In summary, these studies indicate that different epigenetic changes can regulate the epigenome by functioning in concert. 


\section{MicroRNAs: key players in prostate cancer progression}

MicroRNAs (miRNAs) are small non-coding endogenous RNA molecules that bind to target mRNAs with complementary bases to degrade it or attenuate translation ${ }^{[51,52]}$. They play a key role in regulating about $60 \%$ of mRNAs ${ }^{[53,54]}$. Expression profiles of miRNAs in cell lines and clinical samples have been shown to be unique in a large number of studies and miRNAs have been shown to play an important role in the initiation and progression of many diseases including $\mathrm{PCa}^{[55]}$. Therefore, miRNAs have been used as biomarkers and therapeutic targets in diseases ${ }^{[56]}$. In PCa, miRNA levels can be dysregulated by methylation of their promoters or by other tumor-promoting factors or by genomic loss or deletion ${ }^{[57]}$. They can be classified functionally as oncomirs (gain-of-function) or tumor suppressor miRNAs (loss-of-function) based on the roles they play in tumorigenesis ${ }^{[58,59]}$. An important feature of transdifferentiation from an adenocarcinoma state to an NEPC is lack of hormone responsiveness or androgen independence. This is further supported by clinical data from patients where castration-resistant tumors often have focal areas of NE differentiation ${ }^{[60]}$. More studies explore the genetic and epigenetic mechanisms that are activated upon ADTs, eventually leading to the development of NE phenotypes. In a recent study, Zhang et al ${ }^{[61]}$ identified the activation of enhancer of zeste homolog $2(\mathrm{EZH} 2) / \mathrm{cAMP}$ response element-binding protein pathway as a result of androgen deprivation promoting NE differentiation in PCa cell line. In the following section, we will review the role of miRNAs that are either directly associated with development of NEPC or may indirectly be associated with NE differentiation due to their dysregulation upon androgen deprivation [Table 1].

\section{miR-663}

Following a microarray analysis conducted in 127 PCa patients (CRPC and androgen-dependent prostate cancer), expression of miR-663 increased with Gleason score and clinical stage ${ }^{[62]}$. miR-663 expression was studied in androgen-dependent LNCaP cells, castration-therapy resistant subline LNCaP-androgenindependent, castration-therapy resistant DU145, neuroendocrine-like cell line PC3 and nonmalignant prostate epithelial RWPE cells. miR-663 was more highly expressed in PC3 and DU145 cells than in androgen-dependent cells (LNCaP). Interestingly, conversion of androgen-dependent LNCaP cells to castration-therapy resistant LNCaP-AI led to miR-663 overexpression, suggesting that miR-663 may be involved in the transformation from an androgen-dependent to castration-resistant cell type and may also regulate androgen signaling ${ }^{[62]}$. In addition, miR-663 upregulation led to an increase in the expression of NE markers such as SYP, CHGA and ENO2. miR-663 acts by directly targeting dehydrogenase/reductase SDR-family member 7 (DHRS7), NKX3.1, 24-Dehydrocholesterol reductase (DHCR24) and proteasome $20 \mathrm{~S}$ subunit alpha 7 (PSMA7 $)^{[62]}$. The cited study suggests that miR-663 could serve as a prognostic marker and therapeutic target for CRPC. DHCR24 and DHRS7 may play roles in maintaining the synthesis and/ or metabolism of androgens de novo in CRPC, gradually contributing to AR reactivation, enhancing PCa progression even though testicular androgen development is curtailed ${ }^{[6,64]}$. Altered expression of PSMA7 can enhance AR transcriptional activity in CRPC and contribute to hormonal progression of $\mathrm{PCa}^{[64]}$. Downregulation of NKX3.1 promotes cellular proliferation in $\mathrm{CRPC}^{[64]}$.

\section{miR-93, miR-106b and miR-25 cluster}

Hypoxia treatment of neural crest (NC) cell cultures and PCa cell line led to an upregulation of all the miRNAs of the miR-106b 25 cluster (miR-106b, miR-93 and miR-25) ${ }^{[65]}$. The authors proposed that neuronal and neuroendocrine differentiation in NC cells and PCa cells were promoted by hypoxia ${ }^{[65]}$. They suggested that this miR-106b 25 cluster targets and causes a downregulation of the transcriptional repressor RE1-silencing transcription factor (REST), which represses miRNA genes and also neuronspecific protein-coding genes. E2F1and p21/WAF1 were identified as targets of miR-106b, which suppressed the expression of these proteins in LNCaP and PC3 human PCa cells ${ }^{[66]}$. miR-106b-25 cluster directly targets caspase- 7 and phosphatase and tensin homolog (PTEN), contributing to cell proliferation, PCa development and disease recurrence ${ }^{[6]]}$. 
Table 1. Table summarizing the association of miRNAs with NEPC

\begin{tabular}{|c|c|c|c|c|c|c|}
\hline miRNA & Role in & Target & Expression & Altered function & Deregulation & Ref. \\
\hline miR-663 & $\begin{array}{l}\text { NEPC (directly } \\
\text { through } \\
\text { expression of NE } \\
\text { markers) }\end{array}$ & $\begin{array}{l}\text { Chromogranin } \\
\text { A (CHGA), } \\
\text { synaptophysin } \\
\text { (SYP), NSE, DHRS7, } \\
\text { NKX3.1, DHCR24, } \\
\text { PSMA7 }\end{array}$ & Upregulated & Induces NED in cell lines & $\begin{array}{l}\text { Human PCa } \\
\text { LNCaP cell lines, } \\
\text { PC3, Du145 }\end{array}$ & {$[62,141]$} \\
\hline $\begin{array}{l}\text { miR-106b, } \\
\text { miR-93 } \\
\text { and miR-25 } \\
\text { cluster }\end{array}$ & $\begin{array}{l}\text { NEPC } \\
\text { (directly) }\end{array}$ & $\begin{array}{l}\text { RE-1 silencing } \\
\text { transcription factor } \\
\text { (REST), p21/WAF1, } \\
\text { caspase-7 }\end{array}$ & Upregulated & $\begin{array}{l}\text { Induced by hypoxia to } \\
\text { cause NED, disease } \\
\text { progression and } \\
\text { recurrence }\end{array}$ & $\begin{array}{l}\text { Human PCa } \\
\text { LNCaP and PC3 } \\
\text { cell lines }\end{array}$ & {$[65-67]$} \\
\hline $\begin{array}{l}\operatorname{miR}-221- \\
5 p\end{array}$ & $\begin{array}{l}\text { NEPC } \\
\text { (directly) }\end{array}$ & $\begin{array}{l}\text { SOCS1, DVL2 } \\
\text { (dishevelled 2), } \\
\text { p27/Kip1, Ecm29 }\end{array}$ & $\begin{array}{l}\text { Upregulated/ } \\
\text { Downregulated }\end{array}$ & $\begin{array}{l}\text { Regulates proliferation } \\
\text { and migration, induces } \\
\text { NED in LNCaP cells, } \\
\text { plays tumor suppressive } \\
\text { roles }\end{array}$ & $\begin{array}{l}\text { Primary PCa } \\
\text { tumor tissue }\end{array}$ & {$[68,73]$} \\
\hline miR-652 & $\begin{array}{l}\text { NEPC } \\
\text { (directly) }\end{array}$ & PPP2R3A & Upregulated & $\begin{array}{l}\text { Increases } \\
\text { aggressiveness in } \\
\text { prostate cancer, NED, } \\
\text { EMT induction in PC3 } \\
\text { prostate cancer cells }\end{array}$ & $\begin{array}{l}\mathrm{PC} 3 \text { and } \mathrm{LNCaP} \\
\text { cell lines and } \mathrm{PCa} \\
\text { xenograft }\end{array}$ & {$[74]$} \\
\hline miR-301a & $\begin{array}{l}\text { NEPC } \\
\text { (directly) }\end{array}$ & $\begin{array}{l}\beta \text {-Catenin and } \\
\text { E-cadherin, AR, } \\
\text { RUNX3 }\end{array}$ & Upregulated & $\begin{array}{l}\text { Regulates epithelial to } \\
\text { mesenchymal transition } \\
\text { (EMT) in LNCaP cells, } \\
\text { activation of Rho } \\
\text { signaling in DU145 cells, } \\
\text { PCa development and } \\
\text { metastasis }\end{array}$ & $\begin{array}{l}\text { LNCaP-AR, } \\
\text { LNCaP-AR-ENZR } \\
\text { and NCl-H660 } \\
\text { cells }\end{array}$ & {$[76-79]$} \\
\hline miR-708 & $\begin{array}{l}\text { NEPC } \\
\text { (directly) }\end{array}$ & $\begin{array}{l}\text { Sestrin-3, EZH2, } \\
\text { CD44, AKT2 }\end{array}$ & Downregulated & $\begin{array}{l}\text { Involved in NE } \\
\text { differentiation, } \\
\text { apoptosis of prostate } \\
\text { adenocarcinoma cells }\end{array}$ & $\begin{array}{l}\text { Xenograft human } \\
\text { prostate tumors } \\
\text { LAPC- } 4 \text { and } \\
\text { LAPC-9, PC } 3 \text { and } \\
\text { LNCaP cell lines }\end{array}$ & {$[80,81]$} \\
\hline $\operatorname{miR}-125 b$ & $\begin{array}{l}\text { NEPC } \\
\text { (indirectly } \\
\text { through androgen } \\
\text { independence) }\end{array}$ & BAK1, PUMA/BBC3 & Upregulated & $\begin{array}{l}\text { Prostatic tumorigenesis } \\
\text { and androgen- } \\
\text { independent growth }\end{array}$ & LNCaP cell line & {$[55]$} \\
\hline $\begin{array}{l}\text { miR-15a- } \\
\text { miR-16-1 }\end{array}$ & $\begin{array}{l}\text { NEPC } \\
\text { (indirectly } \\
\text { through } \\
\text { chemoresistance) }\end{array}$ & $\begin{array}{l}\text { CCND1 (encoding } \\
\text { cyclin D1) and } \\
\text { WNT3A, Bcl 2, IHH }\end{array}$ & Downregulated & $\begin{array}{l}\text { Tumor suppressors, } \\
\text { cell survival control, } \\
\text { regulate proliferation } \\
\text { and invasion }\end{array}$ & $\begin{array}{l}\text { PCa xenograft } \\
\text { tumor, PC3 cell } \\
\text { line }\end{array}$ & {$[16,84,86]$} \\
\hline $\begin{array}{l}\text { miR-200 } \\
\text { family }\end{array}$ & $\begin{array}{l}\text { NEPC (indirectly } \\
\text { through } \\
\text { chemoresistance) }\end{array}$ & $\begin{array}{l}\text { E-cadherin, ZEB1, } \\
\text { ZEB2 JAGGED }\end{array}$ & Downregulated & $\begin{array}{l}\text { Inhibits migration and } \\
\text { invasion by epithelial- } \\
\text { mesenchymal transition }\end{array}$ & $\begin{array}{l}\text { Metastatic } \\
\text { prostate tissue, } \\
\text { LNCaP cell line, } \\
\text { Du145 cell line, } \\
\text { PC3 cell line }\end{array}$ & {$[84,89,90,93,94]$} \\
\hline miR-320 & CRPC & $\begin{array}{l}\beta-C a t e n i n, \text { LAMP 1, } \\
\text { LEF-1, CD44, SOX9, } \\
\text { Oct-4 and CCND1 }\end{array}$ & Downregulated & $\begin{array}{l}\text { Tumor suppressor, } \\
\text { decreases PCa } \\
\text { tumorigenesis }\end{array}$ & $\begin{array}{l}\text { Primary tumors, } \\
\text { PCa cell lines } \\
\text { PC3, Du145, } \\
\text { LNCaP }\end{array}$ & {$[95,101]$} \\
\hline $\begin{array}{l}\text { miR-31, } \\
\text { miR-205 }\end{array}$ & $\begin{array}{l}\text { NEPC (indirectly } \\
\text { through androgen } \\
\text { independence) }\end{array}$ & $\begin{array}{l}\text { E2F6, Bcl-w, } \\
\text { HRAS, KLK2 } \\
\text { N-chimaerin, ErbB3, } \\
\text { E2F1, E2F5, ZEB2, } \\
\text { protein kinase C } \\
\text { epsilon }\end{array}$ & Downregulated & $\begin{array}{l}\text { Promotes } \\
\text { chemotherapeutic } \\
\text { agent-induced } \\
\text { apoptosis, EMT, inhibits } \\
\text { proliferation }\end{array}$ & $\begin{array}{l}\text { LNCaP, PC3 and } \\
\text { Du145 cell lines }\end{array}$ & {$[102-104,106,107,142]$} \\
\hline miR-21 & $\begin{array}{l}\text { NEPC } \\
\text { (indirectly } \\
\text { through androgen } \\
\text { independence) }\end{array}$ & $\begin{array}{l}\text { PDCD4, TPM1, } \\
\text { RECK, MARCKS }\end{array}$ & Upregulated & $\begin{array}{l}\text { Suppresses a network } \\
\text { of tumor suppressive } \\
\text { pathways }\end{array}$ & $\begin{array}{l}\text { DU145, PC3 and } \\
\text { LNCaP cell lines }\end{array}$ & [109-111] \\
\hline $\begin{array}{l}\text { miR- } \\
\text { 23b/27b } \\
\text { miR34a }\end{array}$ & CRPC & $\begin{array}{l}\text { SIRT1, Bcl 2, CD44, } \\
\text { Rac1, cMyc }\end{array}$ & Downregulated & $\begin{array}{l}\text { Inhibits proliferation, } \\
\text { survival and metastasis }\end{array}$ & $\begin{array}{l}\text { LNCaP-R1, } \\
\text { ALVA31, and PC3 } \\
\text { cell lines, Du145 } \\
\text { cell line }\end{array}$ & {$[27,115,117,118,120,123]$} \\
\hline $\begin{array}{l}\text { miR- } \\
106 a-363 \\
\text { cluster }\end{array}$ & $\begin{array}{l}\text { NEPC } \\
\text { (directly) }\end{array}$ & $\begin{array}{l}\text { Aurora Kinase A, } \\
\text { N-Myc, E2F1 and } \\
\text { STAT3 }\end{array}$ & Downregulated & Tumor suppressor & $\begin{array}{l}\text { Enzalutamide- } \\
\text { resistant LNCaP- } \\
\text { AR cells, PDX } \\
\text { tumors }\end{array}$ & [77] \\
\hline
\end{tabular}




\begin{tabular}{|c|c|c|c|c|c|c|}
\hline miR-375 & $\begin{array}{l}\text { NEPC } \\
\text { (directly) }\end{array}$ & $\begin{array}{l}\text { ENO2, SYP and } \\
\text { CHGA }\end{array}$ & Upregulated & Oncogenic role & $\begin{array}{l}\text { LNCaP-AR, } \\
\text { LNCaP-AR-ENZR } \\
\text { and NCI-H660 } \\
\text { cells }\end{array}$ & [77] \\
\hline miR-146a & CRPC & $\begin{array}{l}\text { ROCK1, EGFR, } \\
\text { MMP2 }\end{array}$ & Downregulated & $\begin{array}{l}\text { Tumor suppressive role, } \\
\text { inhibits metastasis }\end{array}$ & PC3 cell line & {$[124,125]$} \\
\hline
\end{tabular}

Listed are the targets that the miRNAs have been shown to directly repress/alter, observed alteration in the miRNA and the corresponding references. miRNA: microRNA; NEPC: neuroendocrine prostate cancer; NED: neuroendocrine differentiation; PCa: prostate cancer; NE: neuroendocrine; AR: androgen receptor; ROCK1: rho-associated, coiled-coil containing protein kinase 1

\section{miR-221-5p}

From a comprehensive dataset (GSE21036), expression levels of miR-221-5p were analyzed in 218 PCa patients, and it was reported that miR221-5p targets myriad pathways and could act as tumor suppressor or oncomir depending on experimental and cellular conditions ${ }^{[68,69]}$. miR-221-5p is downregulated during PCa progression, suggesting that miR-221-5p acts as a tumor suppressor in PCa patients ${ }^{[68]}$. miR-221-3p can function as an oncomir or tumor suppressor. Its oncogenic role leads to an increase in cell proliferation by targeting and downregulating $\mathrm{p} 27 / \mathrm{Kip} 1^{[68,70,71]}$. miR-221-3p can act as tumor suppressor by targeting Ecm29, an oncogene responsible for metastasis, which was observed to be overexpressed in some CRPC specimens ${ }^{[72]}$. A differential expression analyses showed that miR-221-3p acts as an oncomir that contributes to NE differentiation by targeting dishevelled 2, which may underlie androgen-independent $\mathrm{PCa}^{[70]}$. To further confirm the oncogenic role, an upregulation of miR 221-5p directly targeted suppressor of cytokine signaling 1 which functions in regulating the MAPK/ERK signaling pathway and epithelialmesenchymal transition (EMT) features in PCa cells ${ }^{[73]}$.

\section{miR-652}

Five miRNAs (miRs-301a, 652, 454, 223 and 139) were selected from 33 miRNAs after next-generation miRNA sequencing was performed and were identified to be associated with PCa metastasis ${ }^{[74]}$. The authors selected and functionally characterized miR-652 due to its greater potential to be used as a diagnostic marker and reported that miR-652 plays an oncogenic role by directly targeting the " $\mathrm{B}$ " regulatory subunit $\mathrm{PPP}_{2} \mathrm{R} 3 \mathrm{~A}$ of the tumor suppressor serine/threonine protein phosphatase $2 \mathrm{~A}(\mathrm{PP} 2 \mathrm{~A})$ thus, leading to its increased ability to promote PCa aggressiveness and NED. PP2A acts as an antiapoptotic protein and influences signaling pathways such as the MAP/ERK family of kinases pathway promoting cell growth, proliferation and survival ${ }^{[75]}$.

\section{miR-301a}

Differential expression analysis of miR-301a was observed in PCa samples on the basis of Gleason score and an upregulation of miR-301a in PCa patients with Gleason 6 and Gleason 7 tumors in comparison to benign prostatic hyperplasia $(\mathrm{BPH})^{[76]}$. The cited authors reported that miR-301a does not only promote cell viability but also activates EMT by regulating the expression of $\beta$-catenin and E-cadherin, suggesting that miR-301a is a key driver for enhancing metastatic events in PCa through EMT. Our laboratory recently reported that overexpression of miR-301a leads to induction of NE states coupled with a repression of $\mathrm{AR}^{[77]}$. Upregulated miR-301a was strongly associated with increased Gleason score which inhibits the expression of runt-related transcription factor 3 (RUNX3) indicative of its oncogenic role ${ }^{[78]}$. Altered RUNX3 expression in DU145 cells activates Rho signaling which contributes to PCa development and $\operatorname{metastasis}^{[79]}$.

\section{$\operatorname{miR}-708$}

miR-708 and miR-378c were found to be key miRNAs; after miRNA profiling expression was conducted in luminal PCa cells, their corresponding NEPC cells showed that miR-708 was reduced significantly in NEPC tumors as compared with miR-378c. miR-708 acts by directly targeting sestrin $-3^{[80]}$. The sestrin-3 gene has been identified as a contributing factor in the increase of intracellular reactive oxygen species ${ }^{[80]}$. 
In addition, the reduction of miR-708 activity contributes to the initiation, progression and growth of prostate cancer by controlling the function of both $\mathrm{CD} 44$ and $\mathrm{AKT} 2{ }^{[81]}$. CD44, a cell adhesion molecule, has been identified as a prevalent marker of $\mathrm{PCa}^{[82]}$. Overexpression of $\mathrm{EZH} 2$, a target of miR-708 increased expression of NE markers CHGA and CHGB in PC3 and LNCaP cells ${ }^{[6]}$. EZH2, which is regulated by cyclin-dependent Kinase 1 and Wnt signaling, may also be a contributing factor in the transdifferentiation of PCa cells to NEPC ${ }^{[80]}$.

\section{miR-125b}

miRNA-125b has been shown to be involved in the development of castration resistance ${ }^{[55]}$. Using microarray analysis, the authors analyzed differential expression of 132 miRNAs in androgen-dependent (AD) LNCaP cells and its related androgen-independent (AI) subline $e^{[55]}$. Their data showed that AI LNCaP cells expressed 5 -fold increased levels of miR-125b when compared with the androgen-dependent parental LNCaP cells. This suggests that miRNA-125b may contribute to castration resistance and further progression to NEPC by enhancing androgen independent growth. Furthermore, miR-125b directly targets Bcl2 antagonist/killer 1 (Bak 1) by reducing its expression, thus disrupting mitochondrial apoptosis pathway. miR-125b also targets pro-apoptotic signaling mediators PUMA/BBC3 that displace the inhibitory effect of Bcl2 on Bak1. Confirmatory studies in AD and AI PCa cells have therefore reported that the androgen signaling pathway is able to regulate miR-125b expression, which leads to downregulation of Bak1, hence underscoring the oncogenic effect of miR-125b in stimulating androgen-independent growth of PCa cells ${ }^{[83]}$.

\section{miR 15a and miR-16-1}

miR-15a/miR-16-1 is a cluster that is located at chromosome 13q14, a region which has been shown to be frequently lost in advanced to metastatic PCa, thereby causing downregulation of the cluster ${ }^{[84]}$. Studies in PCa xenograft tumor in vivo detailed that downregulation of mir-15a/miR-16-1 enhances cell survival, proliferation and invasive properties. Loss of $\mathrm{miR}-15 / \mathrm{miR}-16$ plays a synergistic effect along with upregulated miR-21 in increasing aggressiveness and acquisition of a strong EMT phenotype in PCa metastasis ${ }^{[85]}$. miR-15a/miR-16-1 directly targets B-cell lymphoma 2 (Bcl2), cyclin D1 (CCND1) and wingless-type 3A (WNT3A) in advanced $\mathrm{PCa}^{[84]}$. Indian Hedgehog (IHH) was also found to be a direct target of miR-15a/ miR-16-1 cluster by its significant upregulation in cell lines derived from metastatic tumors, specifically the PC3 cell line ${ }^{[85]}$. IHH promotes the proliferation of tumors through direct transcriptional control of the polycomb gene Bmi-1, which has been implicated in PCa development and progression ${ }^{[85]}$. WNT3A signaling increases the expression of $\beta$-catenin and activates survival and proliferation pathways through the phosphorylation of ERK and $\mathrm{Akt}^{[86]}$. Bcl2, an antiapoptotic protein contributes to PCa progression by enhancing the differentiation of $\mathrm{LNCaP} \mathrm{PCa}$ cells from an androgen-dependent to an androgenindependent cell type ${ }^{[87]}$. Cyclin D1 is a positive regulator of cell cycle (G1 phase) that plays a crucial role in tumorigenesis ${ }^{[88]}$. Furthermore, downregulation of miR-15/miR-16 cluster decreases the sensitivity of PCa cells to docetaxel, one of the standard drugs for androgen-independent prostate tumors ${ }^{[86]}$.

\section{miR-200 family}

The miR-200 family, consisting of miR-141, miR-200a, miR-200b, miR-200c and miR-449, is reported to be downregulated during PCa progression; these miRNAs suppress PCa tumor metastasis through the inhibition of EMT, which contributes to chemoresistance ${ }^{[84,89]}$. Low expression levels of ZEB1 and vimentin and a high expression of E-cadherin were reported in the Du145 cell line, upon overexpression of miR-200c suggesting that miR-200c can inhibit PCa cells from proliferating and undergoing EMT, leading to inhibition of invasion and migration ${ }^{[00]}$. Transcription factor ZEB1 regulates gene expression by binding to ZEB-type E-boxes (CACCTG) within the promoter region of the target genes to silence the genes promoting cell migration and tumor metastasis ${ }^{[91,92]}$. ZEB2 is known to downregulate myriad genes that code for crucial proteins responsible for the epithelial phenotype, including E-cadherin ${ }^{[92]}$. In addition, 
miR-200c directly targets JAGGED1, curtailing proliferation of human metastatic PCa cells (PC3 cells) ${ }^{[93]}$. A high level of JAGGED1 shows a positive correlation with PCa recurrence and aggressiveness ${ }^{[94]}$.

\section{$\operatorname{miR}-320$}

miR-320 overexpression in PCa cells plays a tumor-suppressive role by decreasing PCa tumorigenesis in vitro and in vivo through targeting of lymphoid enhancer-binding factor 1 (LEF1), CD44, SOX9, Oct-4 and CCND1, all associated with the Wnt/ $\beta$-catenin signaling pathway ${ }^{[95]}$. LEF1 has been indicated to regulate the expression of $\mathrm{AR}$ and is overexpressed in androgen-independent $\mathrm{PCa}{ }^{[96,97]}$. CCND1 plays a role in the resistance of CRPC patients to ENZ treatment ${ }^{[98]}$. Sox9 enhances the development of PCa to therapy resistance by influencing the activity of the NF-kB pathway ${ }^{[99]}$. Elevated increase in POU transcription factor OCT4 in CRPC patients after docetaxel chemotherapy, suggests its role in tumorigenesis and aggressiveness of $\mathrm{CRPC}^{[100]}$. In addition, miR-320a directly targets lysosomal associated membrane protein 1, which is overexpressed in PC 3 and Du145 cells and CRPC clinical specimens ${ }^{[101]}$.

\section{miR-205 and miR-31}

miR-205 and miR-31 are significantly downregulated in WPE1-NB26 cells, LNCaP, Du145 and in other advanced-stage PCa cell lines ${ }^{[102]}$. Downregulation of these two miRNAs target antiapoptotic genes BCL2L2 (encoding Bcl-w) and E2F6 which are shown to be highly expressed in Du145, LNCaP and PC3 cell lines ${ }^{[102,103]}$. Overexpression of miR-205 in PCa cell lines reduced cell invasion by downregulating protein kinase $\mathrm{C}_{\varepsilon}(\mathrm{PKC} \varepsilon)^{[104]}$. $\mathrm{PKC} \varepsilon$, a serine/threonine kinase member of the PKC subfamily plays a role in sustaining migration and invasion in $\mathrm{PCa}$ with its expression correlating with aggressiveness of the disease by transforming androgen-dependent $\mathrm{LNCaP}$ cells into an androgen-independent variant ${ }^{[105]}$. In addition, miR-205 has been shown to directly target ZEB2, N-chimaerin, ErbB3, E2F1 and E2F5 in PCa cells ${ }^{[104]}$. miR-205 represses ZEB2, resulting in an upregulation of E-cadherin to acquire an epithelial-like phenotype ${ }^{[104]}$. miR-205 downregulation of E2F5, E2F1 and ErbB3, a member of the epidermal growth factor receptor family, could also halt PCa progression and invasive ability ${ }^{[104]}$. miR-205 may act synergistically with miR-130a and miR-203 to repress AR and MAPK, thereby interfering with processes involved in castration resistance ${ }^{[106]}$. Other plausible targets of miR-205 are KLK2 in the human kallikrein gene family and HRAS ${ }^{[106,107]}$.

\section{miR-21}

miR-21 plays an oncogenic role in PCa, and an increase in expression of miR-21 has been shown to correlate with cancer recurrence in PCa patients following radical prostatectomy ${ }^{[89]}$. Overexpression of miR-21 in PC-3 and DU145 cell lines has been shown to contribute to AR-independent PCa growth and also to induce castration resistance phenotype ${ }^{[108]}$. miR-21 directly targets myristoylated alanine-rich protein kinase c substrate (MARCKS) which plays a crucial role in cell motility and invasion in DU145, PC3 and LNCaP cell lines ${ }^{[109]}$. miR-21 also directly targets the matrix metalloproteinase (MMP) inhibitor reversion-inducing cysteine-rich protein with Kazal (RECK) motifs, a key inhibitor of several MMPs, thereby enhancing cell invasion in the Du145 cell line ${ }^{[110]}$. miR-21 has also been studied and proven to partly regulate programmed cell death protein 4 (PDCD4) and tropomyosin 1 (TPM1 $)^{[109]}$. A gain-of-function study conducted on miR21 showed that elevated levels of miR-21 in an androgen-dependent PCa cell line was enough to drive androgen-independent growth ${ }^{[108]}$. Elevated levels of miR-21 in mouse models were found to enhance tumor growth and an induction of a castration-resistant phenotype ${ }^{[108]}$. Functional studies confirmed that an increase in resistance to docetaxel (chemotherapy for CRPC) in PC3 wild-type cells was as a result of overexpression of miR-21 which directly targeted PDCD $4^{[111,112]}$.

\section{miR-23b/27b and miR-34a}

miR-23b and miR-27b cluster is found on human chromosome 9 and has been reported to be downregulated in CRPC tumors ${ }^{[113,114]}$. miR-23b/27b expression was shown to decrease invasiveness in two independent 
aggressive CRPC cell lines, ALVA31 and PC3-ML ${ }^{[115]}$. Downregulation of miR-23b/27b results in decrease in expression of E-cadherin and the increase in Rho GTPase Rac1 activity which plays a key role in aggressive $\mathrm{PCa}$, specifically in the $\mathrm{PC} 3$ cell line, through regulation of cytoskeleton rearrangement essential for cell migration ${ }^{[115,116]}$. The increase in Rac1 activity was also confirmed in the androgen-independent cell lines LNCaP-R1, ALVA31 and PC3 cells compared to the androgen-dependent LNCaP cells ${ }^{[17]}$. Tumor suppressor miR-34a which has been shown to be downregulated in CRPC exerts its action by directly targeting c-myc to inhibit cell migration and invasion particularly in PC3 cell line ${ }^{[118,119]}$. Downregulation of miR-34a has a direct effect on SIRT1 and Bcl2 which leads to the development of paclitaxel resistance in hormone-refractory PCa which causes metastasis and death in CRPC patients ${ }^{[120]}$. In addition, CD44, a cancer stem cell marker has been shown to be selectively expressed in NEPCs ${ }^{[121]}$. A study reported nearly 100\% positive expression of CD44 in PC3 cells and approximately 60\% in DU145 cells ${ }^{[122]}$. miR-34a enhances antitumor and antimetastatic properties in tumorigenic CD44+ PCa cells by directly targeting $\mathrm{CD} 44^{[123]}$.

\section{miR 106a-363 cluster}

Studies conducted in our laboratory using patient samples with CRPC-adeno (CRPC patients with adenocarcinoma features) and CRPC-NE tissues (CRPC patients with NE characteristics) showed that the miR-106a 363 cluster (miR-106a, miR-20b and miR-363) is downregulated in CRPC-NE tissues ${ }^{[77]}$. Expression analyses in PCa cell lines (PC3, LNCaP) compared to BPH1 showed that miR-106a 363 cluster expression was decreased and significantly downregulated in ENZ-resistant LNCaP-AR cells as compared to corresponding parental LNCaP-AR cells, suggesting a correlation between the downregulation of these miRNAs with ENZ resistance. We found that these miRNAs drive NEPC by targeting AURKA, MYCN, E2F1 and STAT3.

\section{miR-375}

Our laboratory performed experiments on patient samples with CRPC-adeno and CRPC-NE tissues and reported that miR-375 was upregulated in CRPC-NE tissue samples ${ }^{[77]}$. Expression analyses in PCa cell lines (PC3 and LNCaP-AR, LNCaP-AR-ENZR and NCI-H660) showed a significant increase in expression of miR-375 suggesting its role in NEPC. We further found an induction of NE genes ENO2, SYP and CHGA by miR-375 overexpression ${ }^{[77]}$.

\section{$\operatorname{miR}-146 a$}

Tumor suppressor miR-146a has been shown to be downregulated in CRPC tissues; miR-146a downregulation inhibited the growth and migratory ability of androgen-independent human CRPC cell lines PC3 and Du145, which may contribute to CRPC progression in these cell lines ${ }^{[124]}$. miR-146a directly targets EGFR through the EGFR/ERK signaling pathways, which enhances proliferation and metastasis in $\mathrm{CRPC}^{[124]}$. Another target for miR-146a was shown to be MMP2, a gene known to promote tumor progression $^{[124]}$. Another study showing the effect of downregulation of miR-146a in androgen-independent PC3 cells reported that increase in expression of Rho-associated, coiled-coil containing protein kinase 1 (ROCK1) enhances cell proliferation, invasion and metastasis by activating the PI3K-mediated Akt/TOR/ eIF4E signaling pathway ${ }^{[125]}$.

\section{MIRNAS AS BIOMARKERS FOR DETECTION AND PROGNOSIS AND THERAPEUTIC TARGETS}

\section{IN NEPC}

A significant number of studies suggest an important role of miRNAs as biomarkers for detection and prognosis in the management of PCa, especially the NE variant ${ }^{[126,127]}$. Some of these miRNAs have also been shown to be a novel therapeutic target in the treatment of advanced forms of PCa. miR-15a and miR-16 which act as tumor suppressors by targeting CCND1, WNT3A and $\mathrm{Bcl} 2$ may be considered to have 
therapeutic potential in NEPC by either acting independently or being used as a combinational therapy with chemotherapy ${ }^{[86]}$. miR-146a, shown to play a tumor suppressive role in androgen-independent prostate cancer, have been postulated as a promising therapeutic target by directly targeting ROCK/caspase 3 pathway ${ }^{[128]}$. miR-573, which targets FGFR1 by modulating EMT and metastasis of PCa cells, may also serve as a therapeutic target or potential biomarker in managing $\mathrm{PCa}^{[129]} . \mathrm{miR}-21$, which has been shown to be an oncomir and plays a critical role in suppressing a network of tumor suppressive pathways by targeting PDCD4 may serve as a therapeutic target or biomarker in $\mathrm{PCa}^{[130]}$. Overexpression of miR-106b, miR-93 and miR-25 cluster may contribute as a clinical biomarker in advanced PCa by targeting transcriptional repressor REST ${ }^{[65]}$. miR-708 could serve as a prognostic marker by targeting EZH2, which binds to the miR-708 promoter and silences it in NEPC ${ }^{[80]}$. miR-652, an oncomir targeting PPP2R3A could function as a biomarker and a therapeutic target for aggressive prostate cancer, considering its contribution to tumor progression by promoting $\mathrm{NED}^{[74]}$. Increased levels of miR-141-3p and miR-375-3p found in plasma may serve as a prognostic marker in predicting progression in mCRPC patients treated with ABI or docetaxel ${ }^{[131]}$. Five miRNAs, miRs-301a, -652, -454, -223 and -139, which have an association with metastasis in PCa, could serve as novel prognostic markers in the management of $\mathrm{PCa}^{[132]}$. miR-301a, which plays an oncogenic role in PCa by targeting AR, could be a potential marker for metastatic conditions in PCa patients ${ }^{[77]}$.

\section{PROS AND CONS OF MIRNAS IN THERAPEUTICS}

Dysregulation of miRNA expression has been implicated in several cancers ${ }^{[133]}$. Treatments based on miRNAs have been fully explored and due to their ability to regulate a wide array of genes by targeting many mRNAs, they can be effective in the control of cancers, thereby having some added advantage over conventional drugs ${ }^{[134]}$. In addition, it is easy to design these miRNA such as miRNA mimics, and these miRNA-based drugs can also be highly specific and potent ${ }^{[135,136]}$. Another advantage of miRNA-based drugs is their small molecular size and low cost of synthesis ${ }^{[134]}$. A major drawback in miRNA-based therapy is with drug delivery; nucleases in serum and cells of the immune system degrade these exposed miRNAs when systematically injected ${ }^{[134,135,137]}$. In addition, due to the fact that miRNAs can target myriad genes, there is a problem of off-target effects which can be lethal to non-targeted cells ${ }^{[138-140]}$.

\section{CONCLUSIONS AND PERSPECTIVES}

Therapy-induced NEPC, which occurs following second-line androgen pathway inhibitor treatment is very aggressive and is associated with poor survival rates. The mechanism for this NED is not yet completely understood. miRNAs have been studied and have been shown to play significant roles in regulating PCa cell growth, apoptosis, invasion and migration abilities. Experiments conducted as discussed in this review, so far have shown a strong correlation of miRNAs with advanced PCa progression. Recent research has also shown that some of these miRNAs can play significant roles in NEPC by acting as oncomirs and tumor suppressors making them very relevant prognostic markers and therapeutic targets in the management of NEPC. However, more miRNA profiling studies need to be conducted to ascertain the etiology of NEPCs since they have not been extensively studied in the field. Also, the functional roles of miRNAs need to be studied in more detail. Eventually, the goal is to translate miRNA research to clinical settings. This field has not yet been investigated and most of the studies have so far focused on preclinical studies on miRNAs.

\section{DECLARATIONS}

\section{Authors' contributions}

Manuscript writing: Akoto T

Proofread and revised the manuscript: Akoto T, Bhagirath D, Saini S 


\section{Availability of data and materials}

Not applicable.

\section{Financial support and sponsorship}

This work was supported by the US Army Medical Research Acquisition Activity (USAMRAA) through the Idea Development Award under Award (No. W81XWH-18-1-0303. Funding support by the National Cancer Institute at the National Institutes of Health (No. RO1CA177984) is also acknowledged.

\section{Conflicts of interest}

All authors declared that there are no conflicts of interest.

\section{Ethical approval and consent to participate}

Not applicable.

\section{Consent for publication}

Not applicable.

\section{Copyright}

(c) The Author(s) 2020.

\section{REFERENCES}

1. Rawla P. Epidemiology of Prostate Cancer. World J Oncol 2019;10:63-89.

2. Siegel RL, Miller KD, Jemal A. Cancer statistics, 2020. CA Cancer J Clin 2020;70:7-30.

3. Ilic D, Djulbegovic M, Jung JH, Hwang EC, Zhou Q, et al. Prostate cancer screening with prostate-specific antigen (PSA) test: a systematic review and meta-analysis. BMJ 2018;362:k3519.

4. Bartzatt R. Prostate Cancer: Biology, Incidence, Detection Methods, Treatment Methods, and Vaccines. Curr Top Med Chem 2020;20:847-54.

5. Nevedomskaya E, Baumgart SJ, Haendler B. Recent Advances in Prostate Cancer Treatment and Drug Discovery. Int J Mol Sci 2018;19:1359.

6. Lipianskaya J, Cohen A, Chen CJ, Hsia E, Squires J, et al. Androgen-deprivation therapy-induced aggressive prostate cancer with neuroendocrine differentiation. Asian J Androl 2014;16:541-4.

7. Li Q, Zhang CS, Zhang Y. Molecular aspects of prostate cancer with neuroendocrine differentiation. Chin J Cancer Res 2016;28:122-9.

8. Aggarwal R, Huang J, Alumkal JJ, Zhang L, Feng FY, et al. Clinical and Genomic Characterization of Treatment-Emergent Small-Cell Neuroendocrine Prostate Cancer: A Multi-institutional Prospective Study. J Clin Oncol 2018;36:2492-503.

9. Lee GT, Rosenfeld JA, Kim WT, Kwon YS, Palapattu G, et al. TCF4 induces enzalutamide resistance via neuroendocrine differentiation in prostate cancer. PLoS One 2019;14:e0213488.

10. Beltran H, Rickman DS, Park K, Chae SS, Sboner A, et al. Molecular characterization of neuroendocrine prostate cancer and identification of new drug targets. Cancer Discov 2011;1:487.

11. Derlin T, Werner RA, Lafos M, Henkenberens C, von Klot CAJ, et al. Neuroendocrine differentiation and response to PSMA-targeted radioligand therapy in advanced metastatic castration-resistant prostate cancer: a single-center retrospective study. J Nucl Med 2020; doi: 10.2967/jnumed.120.241588.

12. Fraser JA, Sutton JE, Tazayoni S, Bruce I, Poole AV. hASH1 nuclear localization persists in neuroendocrine transdifferentiated prostate cancer cells, even upon reintroduction of androgen. Sci Rep 2019;9:19076.

13. Gupta K, Gupta S. Neuroendocrine differentiation in prostate cancer: key epigenetic players. Translat Cancer Res 2017;6:S104-8.

14. Parimi V, Goyal R, Poropatich K, Yang XJ. Neuroendocrine differentiation of prostate cancer: a review. Am J Clin Exp Urol 2014;2:273-85.

15. Borrego-Diaz E, Powers BC, Azizov V, Lovell S, Reyes R, et al. A potential regulatory loop between Lin28B:miR212 in androgenindependent prostate cancer. Int J Oncol 2014;45:2421-9.

16. Chen R, Dong X, Gleave M. Molecular model for neuroendocrine prostate cancer progression. BJU Int 2018;122:560-70.

17. Huang YH, Zhang YQ, Huang JT. Neuroendocrine cells of prostate cancer: biologic functions and molecular mechanisms. Asian J Androl 2019;21:291-5.

18. Hsu TI, Hsu CH, Lee KH, Lin JT, Chen CS, et al. MicroRNA-18a is elevated in prostate cancer and promotes tumorigenesis through suppressing STK4 in vitro and in vivo. Oncogenesis 2014;3:e99.

19. Bidarra D, Constâncio V, Barros-Silva D, Ramalho-Carvalho J, Moreira-Barbosa C, et al. Circulating microRNAs as biomarkers for prostate cancer detection and metastasis development prediction. Front Oncol 2019;9:900. 
20. Luu HN, Lin HY, Sorensen KD, Ogunwobi OO, Kumar N, et al. miRNAs associated with prostate cancer risk and progression. BMC Urol 2017;17:18.

21. Crea F, Venalainen E, Ci X, Cheng H, Pikor L, et al. The role of epigenetics and long noncoding RNA MIAT in neuroendocrine prostate cancer. Epigenomics 2016;8:721-31.

22. Sun Y, Niu J, Huang J. Neuroendocrine differentiation in prostate cancer. Am J Transl Res 2009;1:148-62.

23. Mizokami A, Izumi K, Konaka H, Kitagawa Y, Kadono Y, et al. Understanding prostate-specific antigen dynamics in monitoring metastatic castration-resistant prostate cancer: implications for clinical practice. Asian J Androl 2017;19:143-8.

24. Zhang D, Zhao S, Li X, Kirk JS, Tang DG. Prostate luminal progenitor cells in development and cancer. Trends cancer 2018;4:769-83.

25. Stoyanova T, Cooper AR, Drake JM, Liu X, Armstrong AJ, et al. Prostate cancer originating in basal cells progresses to adenocarcinoma propagated by luminal-like cells. Proc Natl Acad Sci U S A 2013;110:20111-6.

26. Aggarwal R, Zhang T, Small EJ, Armstrong AJ. Neuroendocrine prostate cancer: subtypes, biology, and clinical outcomes. J Natl Compr Canc Netw 2014;12:719-26.

27. Arisan ED, Rencuzogullari O, Freitas IL, Radzali S, Keskin B, et al. Upregulated Wnt-11 and miR-21 expression trigger epithelial mesenchymal transition in aggressive prostate cancer cells. Biology (Basel) 2020;9.

28. Ceder Y, Bjartell A, Culig Z, Rubin MA, Tomlins S, et al. The molecular evolution of castration-resistant prostate cancer. Eur Urol Focus 2016;2:506-13.

29. Czyrnik ED, Wiesehofer M, Dankert JT, Wennemuth G. The regulation of HAS3 by miR-10b and miR-29a in neuroendocrine transdifferentiated LNCaP prostate cancer cells. Biochem Biophys Res Commun 2020;523:713-8.

30. Hsu EC, Rice MA, Bermudez A, Marques FJG, Aslan M, et al. Trop2 is a driver of metastatic prostate cancer with neuroendocrine phenotype via PARP1. Proc Natl Acad Sci U S A 2020;117:2032-42.

31. Aparicio AM, Shen L, Tapia EL, Lu JF, Chen HC, et al. Combined tumor suppressor defects characterize clinically defined aggressive variant prostate cancers. Clin Cancer Res 2016;22:1520-30.

32. Patel GK, Chugh N, Tripathi M. Neuroendocrine differentiation of prostate cancer-an intriguing example of tumor evolution at play. Cancers (Basel) 2019;11.

33. Conteduca V, Oromendia C, Eng KW, Bareja R, Sigouros M, et al. Clinical features of neuroendocrine prostate cancer. Eur J Cancer 2019;121:7-18.

34. Kranitz N, Szepesvary Z, Kocsis K, Kullmann T. Neuroendocrine cancer of the prostate. Pathol Oncol Res 2019; doi: 10.1007/s12253019-00712-2.

35. Bjorkman M, Rantala J, Nees M, Kallioniemi O. Epigenetics of prostate cancer and the prospect of identification of novel drug targets by RNAi screening of epigenetic enzymes. Epigenomics 2010;2:683-9.

36. Blute ML Jr., Damaschke NA, Jarrard DF. The epigenetics of prostate cancer diagnosis and prognosis: update on clinical applications. Curr Opin Urol 2015;25:83-8.

37. Albany C, Alva AS, Aparicio AM, Singal R, Yellapragada S, et al. Epigenetics in prostate cancer. Prostate Cancer 2011;2011:580318.

38. Diaw L, Woodson K, Gillespie JW. Prostate cancer epigenetics: a review on gene regulation. Gene Regul Syst Bio 2007;1:313-25.

39. Jerónimo C, Bastian PJ, Bjartell A, Carbone GM, Catto JWF, et al. Epigenetics in prostate cancer: biologic and clinical relevance. Eur Urol 2011;60:753-66.

40. Nakayama T, Watanabe M, Suzuki H, Toyota M, Sekita N, et al. Epigenetic regulation of androgen receptor gene expression in human prostate cancers. Lab Invest 2000;80:1789-96.

41. Davies A, Zoubeidi A, Selth LA. The epigenetic and transcriptional landscape of neuroendocrine prostate cancer. Endocr Relat Cancer 2020;27:R35-50.

42. Greenberg MVC, Bourc'his D. The diverse roles of DNA methylation in mammalian development and disease. Nat Rev Mol Cell Biol 2019;20:590-607.

43. Park JW, Lee JK, Sheu KM, Wang L, Balanis NG, et al. Reprogramming normal human epithelial tissues to a common, lethal neuroendocrine cancer lineage. Science 2018;362:91-5.

44. McMcCabe MT, Davis JN, Day ML. Regulation of DNA methyltransferase 1 by the pRb/E2F1 pathway. Cancer Res 2005;65:3624-32.

45. Smith BA, Balanis NG, Nanjundiah A, Sheu KM, Tsai BL, et al. A Human Adult Stem Cell Signature Marks Aggressive Variants across Epithelial Cancers. Cell Rep 2018;24:3353-3366.e5.

46. Suh SO, Chen Y, Zaman MS, Hirata H, Yamamura S, et al. MicroRNA-145 is regulated by DNA methylation and p53 gene mutation in prostate cancer. Carcinogenesis 2011;32:772-8.

47. Logothetis CJ, Gallick GE, Maity SN, Kim J, Aparicio A, et al. Molecular classification of prostate cancer progression: foundation for marker-driven treatment of prostate cancer. Cancer Discov 2013;3:849-61.

48. Bannister AJ, Kouzarides T. Regulation of chromatin by histone modifications. Cell Res 2011;21:381-95.

49. Vlachostergios PJ, Papandreou CN. Targeting neuroendocrine prostate cancer: molecular and clinical perspectives. Front Oncol 2015;5:6.

50. Varambally S, Cao Q, Mani RS, Shankar S, Wang X, et al. Genomic loss of microRNA-101 leads to overexpression of histone methyltransferase EZH2 in cancer. Science 2008;322:1695-9.

51. Cannell IG, Kong YW, Bushell M. How do microRNAs regulate gene expression? Biochem Soc Trans 2008;36:1224-31.

52. Cozar JM, Robles-Fernandez I, Rodriguez-Martinez A, Puche-Sanz I, Vazquez-Alonso F, et al. The role of miRNAs as biomarkers in prostate cancer. Mutat Res 2019;781:165-74.

53. Ma G, Tang M, Wu Y, Xu X, Pan F, et al. LncRNAs and miRNAs: potential biomarkers and therapeutic targets for prostate cancer. Am J Transl Res 2016;8:5141-50. 
54. Baumann V, Winkler J. miRNA-based therapies: strategies and delivery platforms for oligonucleotide and non-oligonucleotide agents. Future med chem 2014;6:1967-84.

55. DeVere White RW, Vinall RL, Tepper CG, Shi XB. MicroRNAs and their potential for translation in prostate cancer. Urol Oncol 2009;27:307-11.

56. Vanacore D, Boccellino M, Rossetti S, Cavaliere C, D’Aniello C, et al. Micrornas in prostate cancer: an overview. Oncotarget 2017;8:50240-51.

57. Calin GA, Croce CM. MicroRNA signatures in human cancers. Nat Rev Cancer 2006;6:857-66.

58. Heneghan HM, Miller N, Kerin MJ. MiRNAs as biomarkers and therapeutic targets in cancer. Curr Opin Pharmacol 2010;10:543-50.

59. Svoronos AA, Engelman DM, Slack FJ. OncomiR or Tumor Suppressor? The Duplicity of MicroRNAs in Cancer. Cancer Res 2016;76:3666-70

60. Terry S, Beltran H. The many faces of neuroendocrine differentiation in prostate cancer progression. Front Oncol 2014;4:60.

61. Zhang Y, Zheng D, Zhou T, Song H, Hulsurkar M, et al. Androgen deprivation promotes neuroendocrine differentiation and angiogenesis through CREB-EZH2-TSP1 pathway in prostate cancers. Nat Commun 2018;9:4080.

62. Jiao L, Deng Z, Xu C, Yu Y, Li Y, et al. miR-663 induces castration-resistant prostate cancer transformation and predicts clinical recurrence. J Cell Physiol 2014;229:834-44.

63. Seibert JK, Quagliata L, Quintavalle C, Hammond TG, Terracciano L, et al. A role for the dehydrogenase DHRS7 (SDR34C1) in prostate cancer. Cancer Med 2015;4:1717-29.

64. Romanuik TL, Wang G, Morozova O, Delaney A, Marra MA, et al. LNCaP Atlas: gene expression associated with in vivo progression to castration-recurrent prostate cancer. BMC Med Genomics 2010;3:43.

65. Liang H, Studach L, Hullinger RL, Xie J, Andrisani OM. Down-regulation of RE-1 silencing transcription factor (REST) in advanced prostate cancer by hypoxia-induced miR-106b 25. Exp Cell Res 2014;320:188-99.

66. Ambs S, Prueitt RL, Yi M, Hudson RS, Howe TM, et al. Genomic profiling of microRNA and messenger RNA reveals deregulated microRNA expression in prostate cancer. Cancer Res 2008;68:6162-70.

67. Hudson RS, Yi M, Esposito D, Glynn SA, Starks AM, et al. MicroRNA-106b-25 cluster expression is associated with early disease recurrence and targets caspase-7 and focal adhesion in human prostate cancer. Oncogene 2013;32:4139-47.

68. Kiener M, Chen L, Krebs M, Grosjean J, Klima I, et al. miR-221-5p regulates proliferation and migration in human prostate cancer cells and reduces tumor growth in vivo. BMC Cancer 2019;19:627.

69. Taylor BS, Schultz N, Hieronymus H, Gopalan A, Xiao Y, et al. Integrative genomic profiling of human prostate cancer. Cancer cell 2010;18:11-22.

70. Zheng C, Yinghao S, Li J. MiR-221 expression affects invasion potential of human prostate carcinoma cell lines by targeting DVL2. Med Oncol 2012;29:815-22.

71. Galardi S, Mercatelli N, Giorda E, Massalini S, Frajese GV, et al. miR-221 and miR-222 expression affects the proliferation potential of human prostate carcinoma cell lines by targeting p27Kip1. J Biol Chem 2007;282:23716-24.

72. Goto Y, Kojima S, Nishikawa R, Kurozumi A, Kato M, et al. MicroRNA expression signature of castration-resistant prostate cancer: the microRNA-221/222 cluster functions as a tumour suppressor and disease progression marker. Br J Cancer 2015;113:1055-65.

73. Shao N, Ma G, Zhang J, Zhu W. miR-221-5p enhances cell proliferation and metastasis through post-transcriptional regulation of SOCS1 in human prostate cancer. BMC Urol 2018;18:14.

74. Nam RK, Benatar T, Amemiya Y, Wallis CJD, Romero JM, et al. MicroRNA-652 induces NED in LNCaP and EMT in PC3 prostate cancer cells. Oncotarget 2018;9:19159-76.

75. Silverstein AM, Barrow CA, Davis AJ, Mumby MC. Actions of PP2A on the MAP kinase pathway and apoptosis are mediated by distinct regulatory subunits. Proc Natl Acad Sci U S A 2002;99:4221-6.

76. Damodaran C, Das TP, Papu John AM, Suman S, Kolluru V, et al. miR-301a expression: A prognostic marker for prostate cancer. Urol Oncol 2016;34:336.e13-20.

77. Bhagirath D, Liston M, Patel N, Akoto T, Lui B, et al. MicroRNA determinants of neuroendocrine differentiation in metastatic castrationresistant prostate cancer. Oncogene Forthcoming 2020.

78. Chen F, Wang M, Bai J, Liu Q, Xi Y, et al. Role of RUNX3 in suppressing metastasis and angiogenesis of human prostate cancer. PLoS one 2014;9:e86917.

79. Kolluru V, Chandrasekaran B, Tyagi A, Dervishi A, Ankem M, et al. miR-301a expression: Diagnostic and prognostic marker for prostate cancer. Urol Oncol 2018;36:503.e9-503.e15.

80. Shan J, Al-Muftah MA, Al-Kowari MK, Abuaqel SWJ, Al-Rumaihi K, et al. Targeting Wnt/EZH2/microRNA-708 signaling pathway inhibits neuroendocrine differentiation in prostate cancer. Cell Death Discov 2019, 5: p. 139. [PMC6768854: [DOI: 10.1038/s41420-0190218-y]

81. Saini S, Majid S, Shahryari V, Arora S, Yamamura S, et al. miRNA-708 control of CD44(+) prostate cancer-initiating cells. Cancer Res 2012;72:3618-30.

82. Iczkowski KA. Cell adhesion molecule CD44: its functional roles in prostate cancer. Am J transl res 2010;3:1-7.

83. Shi XB, Xue L, Yang J, Ma AH, Zhao J, et al. An androgen-regulated miRNA suppresses Bak1 expression and induces androgenindependent growth of prostate cancer cells. Proc Natl Acad Sci U S A 2007;104:19983-8.

84. Lo UG, Y ang D, Hsieh JT. The role of microRNAs in prostate cancer progression. Translational andrology and urology 2013;2:228-41.

85. Bonci D, Coppola V, Patrizii M, Addario A, Cannistraci A, et al. A microRNA code for prostate cancer metastasis. Oncogene 2016;35:1180-92. 
86. Bonci D, Coppola V, Musumeci M, Addario A, Giuffrida R, et al. The miR-15a-miR-16-1 cluster controls prostate cancer by targeting multiple oncogenic activities. Nat Med 2008;14:1271-7.

87. Lin Y, Fukuchi J, Hiipakka RA, Kokontis JM, Xiang J. Up-regulation of Bcl-2 is required for the progression of prostate cancer cells from an androgen-dependent to an androgen-independent growth stage. Cell Res 2007;17:531-6.

88. Cao Z, Chen X, Xu Y, Guo F, Ji J, et al. Differential Expression and Prognostic Value of Cytoplasmic and Nuclear Cyclin D1 in Prostate Cancer. Biomed Res Int 2020;2020:1692658.

89. Razdan A, de Souza P, Roberts TL. Role of MicroRNAs in Treatment Response in Prostate Cancer. Curr Cancer Drug Targets 2018;18:929-44.

90. Shi R, Xiao H, Yang T, Chang L, Tian Y, et al. Effects of miR-200c on the migration and invasion abilities of human prostate cancer Du145 cells and the corresponding mechanism. Front Med 2014;8:456-63.

91. Peinado H, Olmeda D, Cano A. Snail, Zeb and bHLH factors in tumour progression: an alliance against the epithelial phenotype? Nat Rev Cancer 2007;7:415-28.

92. Kong D, Li Y, Wang Z, Banerjee S, Ahmad A, et al. miR-200 regulates PDGF-D-mediated epithelial-mesenchymal transition, adhesion, and invasion of prostate cancer cells. Stem Cells 2009;27:1712-21.

93. Vallejo DM, Caparros E, Dominguez M. Targeting Notch signalling by the conserved miR-8/200 microRNA family in development and cancer cells. EMBO J 2011;30:756-69.

94. Santagata S, Demichelis F, Riva A, Varambally S, Hofer MD, et al. JAGGED1 expression is associated with prostate cancer metastasis and recurrence. Cancer Res 2004;64:6854-7.

95. Hsieh IS, Chang KC, Tsai YT, Ke JY, Lu PJ, et al. MicroRNA-320 suppresses the stem cell-like characteristics of prostate cancer cells by downregulating the Wnt/beta-catenin signaling pathway. Carcinogenesis 2013;34:530-8.

96. Li Y, Wang L, Zhang M, Melamed J, Liu X, et al. LEF1 in androgen-independent prostate cancer: regulation of androgen receptor expression, prostate cancer growth, and invasion. Cancer research 2009;69:3332-8.

97. Yang X, Chen MW, Terry S, Vacherot F, Bemis DL, et al. Complex regulation of human androgen receptor expression by Wnt signaling in prostate cancer cells. Oncogene 2006;25:3436-44.

98. Pal SK, Patel J, He M, Foulk B, Kraft K, et al. Identification of mechanisms of resistance to treatment with abiraterone acetate or enzalutamide in patients with castration-resistant prostate cancer (CRPC). Cancer 2018;124:1216-24.

99. Nouri M, Massah S, Caradec J, Lubik AA, Li N, et al. Transient Sox9 expression facilitates resistance to androgen-targeted therapy in prostate cancer. Clin Cancer Res 2020; doi: 10.1158/1078-0432.CCR-19-0098.

100. Kosaka T, Mikami S, Yoshimine S, Miyazaki Y, Daimon T, et al. The prognostic significance of OCT4 expression in patients with prostate cancer. Human Pathol 2016;51:1-8.

101. Okato A, Goto Y, Kurozumi A, Kato M, Kojima S, et al. Direct regulation of LAMP1 by tumor-suppressive microRNA-320a in prostate cancer. Int J Oncol 2016;49:111-22.

102. Bhatnagar N, Li X, Padi SK, Zhang Q, Tang MS, et al. Downregulation of miR-205 and miR-31 confers resistance to chemotherapyinduced apoptosis in prostate cancer cells. Cell Death Dis 2010;1:e105.

103. Fuse M, Kojima S, Enokida H, Chiyomaru T, Yoshino H, et al. Tumor suppressive microRNAs (miR-222 and miR-31) regulate molecular pathways based on microRNA expression signature in prostate cancer. J Hum Genet 2012;57:691-9.

104. Gandellini P, Folini M, Longoni N, Pennati M, Binda M, et al. miR-205 Exerts tumor-suppressive functions in human prostate through down-regulation of protein kinase Cepsilon. Cancer Res 2009;69:2287-95.

105. Wu D, Foreman TL, Gregory CW, McJilton MA, Wescott GG, et al. Protein kinase cepsilon has the potential to advance the recurrence of human prostate cancer. Cancer Res 2002;62:2423-9.

106. Boll K, Reiche K, Kasack K, Mörbt N, Kretzschmar AK, et al. MiR-130a, miR-203 and miR-205 jointly repress key oncogenic pathways and are downregulated in prostate carcinoma. Oncogene 2013;32:277-85.

107. Diamandis EP, Yousef GM, Luo LY, Magklara A, Obiezu CV. The new human kallikrein gene family: implications in carcinogenesis. Trends Endocrinol Metab 2000;11:54-60.

108. Ribas J, Lupold SE. The transcriptional regulation of miR-21, its multiple transcripts, and their implication in prostate cancer. Cell Cycle 2010;9:923-9.

109. Li T, Li D, Sha J, Sun P, Huang Y. MicroRNA-21 directly targets MARCKS and promotes apoptosis resistance and invasion in prostate cancer cells. Biochem Biophys Res Commun 2009;383:280-5.

110. Reis ST, Pontes-Junior J, Antunes AA, Dall'Oglio MF, Dip N, et al. miR-21 may acts as an oncomir by targeting RECK, a matrix metalloproteinase regulator, in prostate cancer. BMC Urol 2012;12:14.

111. Shi GH, Ye DW, Yao XD, Zhang SL, Dai B, et al. Involvement of microRNA-21 in mediating chemo-resistance to docetaxel in androgenindependent prostate cancer PC3 cells. Acta Pharmacol Sin 2010;31:867-73.

112. Teply BA, Hauke RJ. Chemotherapy options in castration-resistant prostate cancer. Indian J Urol 2016;32:262-70.

113. Sun T, Yang M, Chen S, Balk S, Pomerantz M, et al. The altered expression of MiR-221/-222 and MiR-23b/-27b is associated with the development of human castration resistant prostate cancer. Prostate 2012;72:1093-103.

114. Hannafon BN, Cai A, Calloway CL, Xu Y-F, Zhang R, et al. miR-23b and miR-27b are oncogenic microRNAs in breast cancer: evidence from a CRISPR/Cas9 deletion study. BMC Cancer 2019;19:642.

115. Ishteiwy RA, Ward TM, Dykxhoorn DM, Burnstein KL. The microRNA -23b/-27b cluster suppresses the metastatic phenotype of castration-resistant prostate cancer cells. PLoS One 2012;7:e52106.

116. Kobayashi T, Inoue T, Shimizu Y, Terada N, Maeno A, et al. Activation of Rac1 is closely related to androgen-independent cell 
proliferation of prostate cancer cells both in vitro and in vivo. Mol Endocrinol 2010;24:722-34.

117. Knight-Krajewski S, Welsh CF, Liu Y, Lyons LS, Faysal JM, et al. Deregulation of the Rho GTPase, Rac1, suppresses cyclin-dependent kinase inhibitor p21CIP1 levels in androgen-independent human prostate cancer cells. Oncogene 2004;23:5513-22.

118. Yamamura S, Saini S, Majid S, Hirata H, Ueno K, et al. MicroRNA-34a modulates c-Myc transcriptional complexes to suppress malignancy in human prostate cancer cells. PLoS One 2012;7:e29722.

119. Chalanqui MJ, O’Doherty M, Dunne NJ, McCarthy HO. MiRNA 34a: a therapeutic target for castration-resistant prostate cancer. Expert Opin Ther Targets 2016;20:1075-85.

120. Kojima K, Fujita Y, Nozawa Y, Deguchi T, Ito M. MiR-34a attenuates paclitaxel-resistance of hormone-refractory prostate cancer PC3 cells through direct and indirect mechanisms. Prostate 2010;70:1501-12.

121. Simon RA, di Sant'Agnese PA, Huang LS, Xu H, Yao JL, et al. CD44 expression is a feature of prostatic small cell carcinoma and distinguishes it from its mimickers. Hum Pathol 2009;40:252-8.

122. Palapattu GS, Wu C, Silvers CR, Martin HB, Williams K, et al. Selective expression of CD44, a putative prostate cancer stem cell marker, in neuroendocrine tumor cells of human prostate cancer. Prostate 2009;69:787-98.

123. Liu C, Kelnar K, Liu B, Chen X, Calhoun-Davis T, et al. The microRNA miR-34a inhibits prostate cancer stem cells and metastasis by directly repressing CD44. Nat Med 2011;17:211-5.

124. Xu B, Wang N, Wang X, Tong N, Shao N, et al. MiR-146a suppresses tumor growth and progression by targeting EGFR pathway and in a p-ERK-dependent manner in castration-resistant prostate cancer. Prostate 2012;72:1171-8.

125. Lin SL, Chiang A, Chang D, Ying SY. Loss of mir-146a function in hormone-refractory prostate cancer. RNA 2008;14:417-24.

126. Kanwal R, Plaga AR, Liu X, Shukla GC, Gupta S. MicroRNAs in prostate cancer: Functional role as biomarkers. Cancer Lett 2017;407:9-20.

127. Kim WT, Kim WJ. MicroRNAs in prostate cancer. Prostate Int 2013;1:3-9.

128. Xu B, Huang Y, Niu X, Tao T, Jiang L, et al. Hsa-miR-146a-5p modulates androgen-independent prostate cancer cells apoptosis by targeting ROCK1. Prostate 2015;75:1896-903.

129. Wang L, Song G, Tan W, Qi M, Zhang L, et al. MiR-573 inhibits prostate cancer metastasis by regulating epithelial-mesenchymal transition. Oncotarget 2015;6:35978-90.

130. Li T, Li RS, Li YH, Zhong S, Chen YY, et al. miR-21 as an independent biochemical recurrence predictor and potential therapeutic target for prostate cancer. J Urol 2012;187:1466-72.

131. Zedan AH, Osther PJS, Assenholt J, Madsen JS, Hansen TF. Circulating miR-141 and miR-375 are associated with treatment outcome in metastatic castration resistant prostate cancer. Sci Rep 2020;10:227.

132. Nam RK, Amemiya Y, Benatar T, Wallis CJ, Stojcic-Bendavid J, et al. Identification and validation of a five microRNA signature predictive of prostate cancer recurrence and metastasis: a cohort study. J Cancer 2015;6:1160-71.

133. Andersen GB, Tost J. Circulating miRNAs as biomarker in cancer. Recent Results Cancer Res 2020;215:277-98.

134. Yeung ML, Jeang KT. MicroRNAs and cancer therapeutics. Pharm Res 2011;28:3043-9.

135. Ahmadzada T, Reid G, McKenzie DR. Fundamentals of siRNA and miRNA therapeutics and a review of targeted nanoparticle delivery systems in breast cancer. Biophys Rev 2018;10:69-86.

136. Lam JK, Chow MY, Zhang Y, Leung SW. siRNA Versus miRNA as Therapeutics for Gene Silencing. Mol Ther Nucleic Acids 2015;4:e252.

137. Fabris L, Ceder Y, Chinnaiyan AM, Jenster GW, Sorensen KD, et al. The potential of microRNAs as prostate cancer biomarkers. Eur Urol 2016;70:312-22

138. Ishida M, Selaru FM. miRNA-Based Therapeutic Strategies. Curr Anesthesiol Rep 2013;1:63-70.

139. Li C, Feng Y, Coukos G, Zhang L. Therapeutic microRNA strategies in human cancer. AAPS J 2009;11:747-57.

140. Rothschild SI. microRNA therapies in cancer. Mol Cell Ther 2014;2:7.

141. Lin CJ, Lo UG, Hsieh JT. The regulatory pathways leading to stem-like cells underlie prostate cancer progression. Asian J Androl 2019;21:233-40

142. Lin PC, Chiu YL, Banerjee S, Park K, Mosquera JM, et al. Epigenetic repression of miR-31 disrupts androgen receptor homeostasis and contributes to prostate cancer progression. Cancer Res 2013;73:1232-44. 